AGRARIS: Journal of Agribusiness and Rural Development Research

Vol. 6 No. 2: July-December 2020

Article history:

Submitted: August $2^{\text {nd }}, 2020$

Accepted: September $23^{\text {rd }}, 2020$
Malose M. Tjale, Marizvikuru Mwale* and Beata M. Kilonzo

University of Venda, Institute for Rural Development, South Africa

*)Correspondence email: marizvikuru.manjoro@univen.ac.za

\title{
Intervention Strategy for Enhancing Livelihoods of Land Reform Farmers in Waterberg District, South Africa
}

\author{
DOI: https://doi.org/10.18196/agr.6299
}

\begin{abstract}
Despite South Africa implementing various land reform policies post 1994 to address poverty and inequality, poor performance of restitution farms and unimproved livelihoods of farm beneficiaries still exist. Hence, the objective of the study was to develop an intervention strategy between July 2016 and June 2017, to improve livelihoods of farm beneficiaries in South Africa and beyond. Quantitative and qualitative methods were used to collect and analyse data. Transformative research design was used. Focus group discussions, nonparticipatory observation, interviews and feedback sessions were used to collect qualitative data from 26 key informants in Waterberg District. A questionnaire was utilized to collect quantitative data from 289 farm beneficiaries drawn from 32 farms in the District. Qualitative data, was analysed using Thematic content while Statistical Package for the Social Sciences (SPSS) version 25 was used for quantitative data. Ranking analysis was performed to determine factors contributing to non-performance of the farms. Majority of respondents $(84.4 \%)$ agreed that farm production decreased and beneficiaries' livelihoods remained the same since restoration. Therefore, an intervention strategy that included support production system, improved market access and incorporation of agricultural economic experts and engineers was developed to unleash agricultural potential in restitution farms.
\end{abstract}

Keywords: Farm performance, Intervention strategy, Land restitution, Restitution farm, Rural livelihoods

\section{INTRODUCTION}

Worldwide, countries have implemented land reform programmes to address the challenges of poverty and inequality (Lipton, 2012). The programmes are also meant to provide people with important livelihood opportunities, such as livestock rearing, crop production and game farming in order to increase income, power and status (Lipton, 2012). In South Asia state-led land reforms are widely regarded as having met the objective and delivered significant benefits by decreasing absolute landlessness and reducing poverty because of predominant market-orientation policy. However, there were several challenges experienced by the farm beneficiaries that ultimately hinder the restitution farms from improving their livelihoods, hence, this study is intended to develop an intervention strategy to enhance productive utilization of the farms that may lead to sustainability and 
improvement in the livelihood of the farm beneficiaries. In China "household contract responsibility strategy was implemented to deal with land reform issues in the rural areas since 1978. However, the system was ineffective, and farmers failed to increase income from their farms" (Jiming, 2013). Since 2000, Zimbabwe has implemented the Fast Track Land Reform Programme (FTLRP) to speed up the distribution of land to indigenous people. Unfortunately, the agricultural production declined and the entire economy has shrunk by approximately $40 \%$ (Nyawo, 2014). The land reform programme in South Africa was not different from that of other nations. It arose from the need to redress the past historical and socio-economic injustice imposed on the people by the former apartheid form of government (Mabuza, 2016). The programme addressed three strategic sub-programmes which are: Land Tenure, Land Redistribution and Land Restitution to alleviate poverty and improve livelihoods of the land reform farm beneficiaries. However, most analysts are of the view that South Africa `s post-1994 land reform programme has been a dismal failure (Hendricks et al., 2013).

Although land reform policies were developed in South Africa post 1994 such as Land Reform Policy Discussion Document, Willing-Seller Willing-Buyer policy and Proactive Land Acquisition Strategy (PLAS), there was no intervention strategy that could be used, in particular for the restituted farms beneficiaries to enhance their livelihoods. However, land reform as a systematic solution to deal with a number of socio-economic factors faced by many people in the world, should be implemented correctly to benefit the poor beneficiaries (Maboa, 2014). The ownership and control of land remain highly sensitive in Africa, and particularly in countries with a history of settler colonialism (Pilossof, 2016). Added to this, Mabuza (2016) indicated that Africa, been the most affected continent due to colonisation by the western countries where land dispossession has resulted in poverty, food insecurity, loss of income, skewed land ownership and poor economy in general, this affected land reform in several countries such as Namibia, Kenya, Rwanda, Zimbabwe and South Africa to battle over land and agricultural resources (Maboa, 2014). This include Waterberg District where the study has been conducted.

In South Africa, in the year 2006/2007, the Department of Rural Development and Land Reform (DRDLR) allocated 32 restitution farms to beneficiaries in Waterberg District (DRDLR, 2013). The objective was to improve rural livelihoods and alleviate poverty but failure of the programme rather compromised the farm beneficiaries' livelihoods (Pringle, 2013). Added to this, the unimpressive results of the land reform programme indicated the failure of the programmes to fight poverty, inequality and social exclusion (Walker, 2012). About $90 \%$ of the land acquired by the state and allocated to emerging farmers became unproductive, and this notion was supported by the government which also admitted that $90 \%$ of these farming projects failed to be productive (Kloppers, 2014). The unproductivity of the restitution farms, thus, rather increased the levels of poverty among the beneficiaries instead of breaking the circle of poverty. As an example, Aliber \& Cousins (2013) indicate unsuccessful outcomes of the performance of the 117 land reform farms in Capricorn and Vhembe Districts in Limpopo province. Out of 117 land reform farms, 81 were redistribution 
and 36 were restitution, however, Aliber \& Cousins (2013) confirm that by 2007, only 46\% of the farms were not effective, and $40 \%$ activities of beneficiaries on the land were noticeable. Farms that had no beneficiary involvement were at $3 \%$, while $10 \%$ of the farms had no information which suggest that the land was not being effectively used. Most of the restitution farmers failed to produce due to little or no farming activities.

Furthermore, a study carried out by Mutanga (2011) revealed that the previously productive Lisbon Estate which exported citrus fruit and mangoes in Mpumalanga Province, had failed to produce after land was given back to its rightful owners who were disadvantaged of their land. Timongo subtropical fruits and nuts farm in the Levubu Valley of the Limpopo Province is another farm which failed after it was restored to two communities that initiated a co-operation as strategic partners, however, due to an extended restitution process there was an estimated $40 \%$ decline in employment of the existing workforce (Hall et al., 2013). The existing workers who were distinct interest groups and dwellers were generally ignored in the restitution process. In the South African context, several land reform policies such as Land Reform Policy Discussion Document of 2012, Willing-Buyer Willing-Seller policy 1995 and Proactive Land Acquisition Strategy of 2006, have been implemented to address inequality in land ownership. However, poor farms performance and unimproved livelihoods of beneficiaries still exist. The emphasis on land reform which carry additional strategic significance of giving land to the poor people to achieve economic and social equity and create more employment among those who received land was failing, and its objective is largely not been achieved (Cousins, 2019). Hence, the current study was undertaken to develop a threepronged intervention strategy to help land reform farm beneficiaries in Waterberg District and entire South Africa, to realise sufficient production that could ultimately enhance their livelihoods.

\section{RESEARCH METHOD}

\section{Description of The Study Area}

The study was conducted at Waterberg District Municipality in Limpopo Province of South Africa. The District shares boundaries with Botswana to the North-western and to the East is the Greater Sekhukhune District Municipality North-East, is Capricorn District Municipality while to the South of the District is Gauteng province, and finally, to the Southwestern of the District is North West province (Waterberg District Municipality Integrated Development Plan (WDM IDP), 2018). There are six towns and 10 townships within the District (WDM IDP, 2018). The District covers an area of 44913 square kilometres, consisting of 4951882 hectares (STATS SA, 2011). The estimated number of people living within the District is 679 336, with an estimated 179866 households (STATS SA, 2011). The area falls within the summer rainfall region of Limpopo Province, with the average annual rainfall of 600 and $650 \mathrm{~mm}$ occurring in January and December, and agricultural potential is associated with topographical soils (WDM IDP, 2018). The overall employment level, measured simply by the total number of people who are either formally or informally employed, has decreased by an average of $1.07 \%$ per annum since 1995 (Waterberg Local Economic Development 
(LED), 2014). The unemployment rate is higher in the District at 28.1\%, which is higher than the 20,3\% of the entire Limpopo province (STATS SA, 2019). The District municipality consists of six local municipalities with 79 wards (WDM IDP, 2018). As shown in Figure 1, the local municipalities are Mogalakwena, Mookgophong, Modimolle, Belabela, Thabazimbi and Lephalale, and most of the farms are predominantly in Mogalakwena and Mookgophong. (Waterberg District Municipality IDP, 2013). Although the District consists of 79 wards, not all the wards participated in this study, as focus was only on the wards where restitution farms are located.

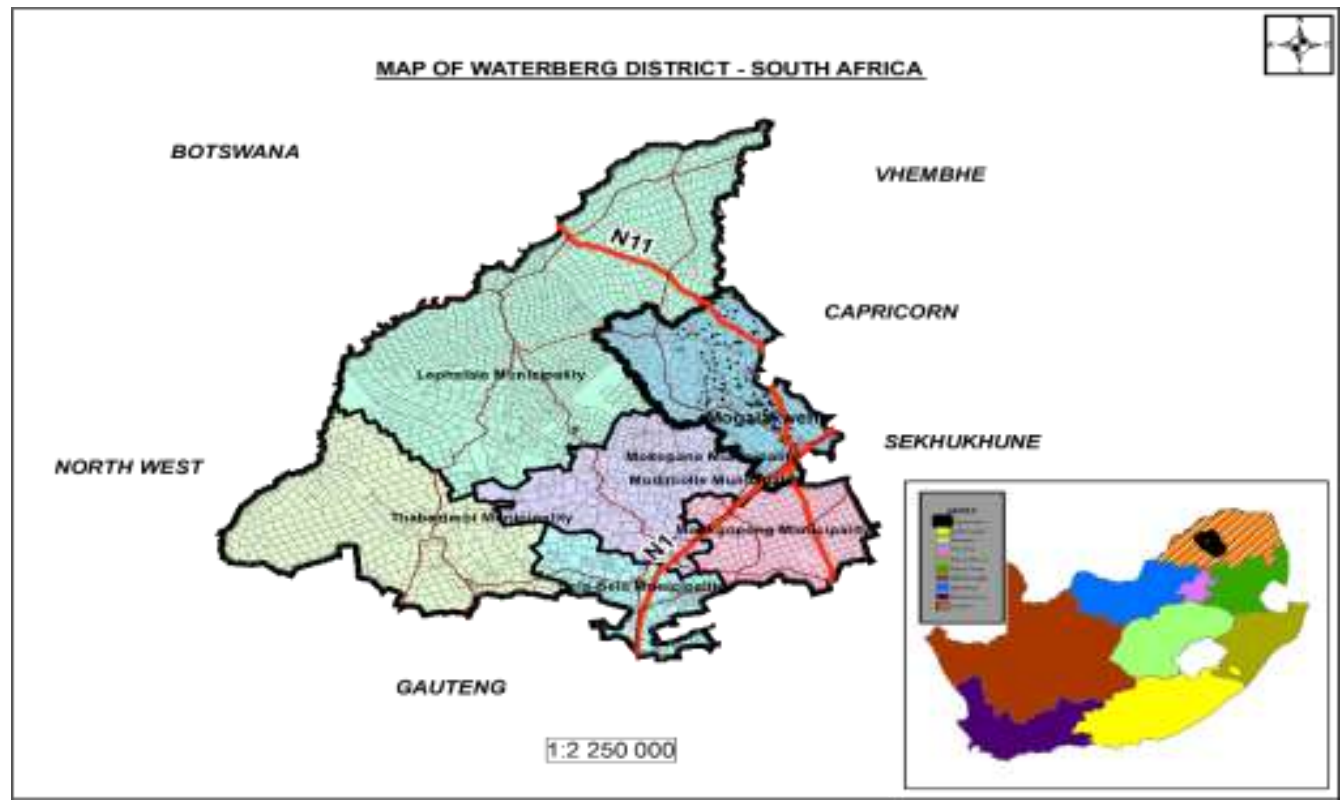

Source: Waterberg District Municipality IDP (2018)

FIGURE 1. MAP OF THE STUDY AREA, WATERBERG DISTRICT

\section{Research Design}

A transformative research design was applied using quantitative approach. A questionnaire with close-ended questions was used to collect data through a farm survey to study important issues on the livelihoods of farm beneficiaries. The design address issues of the land dispossession as well as influences change on the marginalized farm beneficiaries through the restitution programme. The rationale for using a transformative research design was to upsurge the probability of the marginalized restitution farm beneficiaries being adequately represented and to encourage them to participate in the study. Data from the farm beneficiaries included records for the restitution farms in Waterberg district thereby conforming to a case study approach, and essential issues on farm production.

\section{Population and sampling Methods}

The study was based on the emancipatory research paradigm. It was conducted between July 2016 and June 2017 with the aim of gathering inputs from the research participants; that informed the development of the intervention strategy. The strategy is envisaged to bring solutions to problems experienced by farm beneficiaries at restitution farms. The population target of 4445 with a sample size of 474 was used for this study. Out 
of the population, 4409 were farm beneficiaries from 32 farms and 36 key stakeholders who were 22 ward Councillors, seven traditional leaders from the areas or wards where restitution farms are located, six Agricultural Extension Officials and one officer from Department of Rural Development and Land Reform (DRDLR) who was working in the Waterberg District. Furthermore, 64 are executive members of the farms either as chairpersons or secretaries, hence, a chairperson and a secretary from each of the 32 farms formed part of the sampling size; the remaining 384 participants were ordinary farm beneficiaries who are not in the executive committee, and 12 farm beneficiaries were selected from each of the 32 farms to form part of the sample size. The study used stratified sampling method based on convenient and probability type of sampling to select 474 respondents. The aim to choose stratified sampling method was to conveniently study different types of restitution farms and their impact on improving livelihoods of the farm beneficiaries. The 32 restitution farms are differentiated according to the following seven categories: (a) livestock farming, (b) crop farming, (c) game farming, (d) livestock and crop farming, (e) game and livestock farming, (f) game and crop farming as well as (g) game, crop and livestock farming. The aim for using the stratified sampling method was also to study the livelihoods of the farm beneficiaries who come from the seven different categories of restitution farms. However, out of the sample size of 474 , only 289 respondents managed to participate in the study. That means out of the 289 respondents, 263 farm beneficiaries and 26 key stakeholders managed to participate actively in the study. However, during the feedback session, 72 participants managed to come, that is, 64 farm beneficiaries, two from each farm represented by the chairperson and one member of the farm. The other respondents who came were five (5) Chiefs, three (3) officials from the Department of Agriculture and one (1) official from DRDLR.

\section{Data collection methods}

Focus-group discussions (FGDs), non-participatory observation, interviews, and feedback session were used to collect qualitative data from 26 key informants, while quantitative data was collected using a structured questionnaire to interview 263 farm beneficiaries coming from the 32 farms. Observation method was employed during the interviews to observe the status of the farms and behaviours of farm beneficiaries when working on farms. Feedback workshop was used for confirmation of findings and gap filling of data that might have been omitted during the first visit of collecting data. In order to finalize the developed intervention strategy, the information drawn from the feedback session method contributed significantly. The feedback session was conducted at Modimolle local Municipality and about 72 farm beneficiaries and key stakeholders who were interviewed during the study participated. These came through invitation and were from the 32 farms who initially participated in studies on land restitution. During the feedback workshop session, previous research findings were presented and participants confirmed and added new facts emanating from the study area. 


\section{Data analysis method}

As part of data management, there are certain preliminaries that were done prior the collection and actual analysis of data. The data management plan included identifying software and creating templates for capturing and storing data, organising who accesses the data, having password encryption on the datasets and securing lockable cabinets for storage of data in print. The data storage was pegged at 5 years to allow verification and publication purposes. Before analysis, data was recorded and cleaned through correcting errors. Out of the four types of data measurements which are nominal, ordinal, interval and ratio; mainly the first three were used to depict the relationship between land reform farms and the improvement of livelihoods of the land reform farm beneficiaries. The Statistical Package for the Social Science (SPSS version 25) was used as a tool to analyse the quantitative data from the questionnaires. Ranking analysis was used to sort the factors that determined the performance or non-performance of farms by importance. The SPSS was also used to compute descriptive statistics of the farm beneficiaries within the restitution farms. The aim of using SPSS was to systematically reorganize raw quantitative data on a specifically developed form to analyse and to interpret descriptive statistics and rankings. Transcription of interviews, coding and computer spreadsheet as data analysis techniques were used to compute statistics that determine the relationships of certain variables, such as year in which the farm was restored, income of the farms, income of the individual beneficiaries, education levels, age of beneficiaries, number of dependents within the beneficiaries' households, number of years working on the farm, producing frequencies and production percentages. For Qualitative data from interviews, FGDs and observation methods, thematic content analysis was used to compute themes, patterns, coding relationships and tree diagrams, and to get participants' experience and opinions that informed the development of the intervention strategy.

\section{Limitations of the methodology used in the study}

Feedback sessions are very important in a research because they provide opportunity for confirmation of findings and fill any gaps that might have been omitted during the time of data collection. However, during the session some farm beneficiaries who came were not those who were selected and interviewed during data collection. This situation caused lack of consistency of some of the data and making it invalid. However, during the plenary session prior feedback session, the researcher identified first those who were present during data collection and obtained the missing information, and later gave opportunity to farm beneficiaries who did not participate during the data collection phase to contribute. The beneficiaries provided valuable inputs that was infused into the intervention strategy.

\section{Ethical Considerations}

Research ethics were adhered to during the collection, analysis and storage of data. The ethics entailed but not limited to respect, avoiding harm to respondents, confidentiality, avoiding deception during research, security of data storage and permission to publish the study. Above all, institutional ethical clearance from the University of Venda Research Ethics Committee was secured for permission to conduct the study (SARDF/16/IRD/06). Finally, 
permission in writing was secured from the DRDLR, WDM, Department of Agriculture and House of Traditional leaders to carry out the study. Regarding Community entry, prior to data collection, the locally acceptable protocols were adhered to when meeting with the relevant structures in the communities.

\section{RESULTS AND DISCUSSIONS}

The South African government embarked on land reform programme since 1995 with the main aim to redress the previous injustice on land ownership imposed on the people by the former apartheid regime (Zenker, 2014). This land reform programme was implemented in the whole of South Africa including Waterberg District where the study was conducted. Prior 1995, land dispossession produced bad experiences among the poor the land reform farm beneficiaries in South Africa like inequitable distribution of land ownership largely in favour of the white minority, unproductive farms and dislocation of the indigenous people in relation to social and economic land use (Land Reform Policy Discussion Document, 2012). Thus, the government of South Africa has embarked on land reform to redress the inequalities and injustices of the past caused by the former apartheid regime. Generally, the impact of land reform programme in particular land reform farms is not effective in South Africa (Mutanga, 2011). Above all, most of the farms recipients have had their farms back for more than fifteen years, yet the objective of land reform programme to improve rural livelihoods and alleviate poverty among the land reform beneficiaries was not accomplished (Pringle, 2013). As such, the current study was undertaken to develop a three-pronged intervention strategy to help land reform farm beneficiaries in Waterberg District of Limpopo Province, South Africa to improve their livelihoods. The results of the current study are presented and discussed below.

\section{Farm performance}

Most of the farm beneficiaries (84.4\%) strongly agreed that farm production has decreased since restoration of the farms. During feedback session on the 08 July 2017, most of the farm beneficiaries commented that, "livelihoods were not improved because of lack of production in the farms. Respondents emphasised that the same lack of production was caused by Department of Rural Development and Land reform (DRDLR), which brought mentors who were not capacitated in farming to transfer skills to the beneficiaries”. Many times when money to pay the mentors was exhausted, mentors would withdraw their services from the farms. This hindered farm beneficiaries from obtaining continuous training on farming. Another main cause of poor production and underutilisation of the farms highlighted by farm beneficiaries was that "the DRDLR hired more than fifty percent of the staff who do not know much about land reform issues". The beneficiaries gave examples, such as officials who do not understand what a business plan is all about. "When DRDLR official resigns for greener pastures, the new employee starts the process of compiling a business plan from the beginning which delays the process of funding until the farm bank accounts were closed", hence, most of the farms could not access the funding promised by the DRDLR because of delays caused by the internal disorganisation in the DRDLR. 
Although the South African government implemented some land reform strategies to transform the socio-economic status of the land reform farm beneficiaries, however, majority of the farm beneficiaries strongly agreed to the notion that performance of the restitution farms is not satisfactory, and the rural livelihoods of the land reform farm beneficiaries are still the same. In support of the above statement, Golele (2016), conducted a study in 2014 to 2015 that revealed farms that were obtained through restitution programmes in Sekhukhune District in Limpopo Province not functioning at all, while others merely operate at a subsistence level. An empirical study was conducted in KwaZulu-Natal Province to compare the output of the sugar farmland prior and after transfer to smallholder farmers in Uthungulu and iLembe areas (Van Rooyen, 2008). The results showed that half of the farms productivity declined 'during the year of takeover'. Consequently, this clearly indicated that the majority of land reform farms did not perform well in terms of productivity to improve the livelihoods of the farms.

\section{Monitoring of the restitution farms}

About $50.5 \%$ (146 farm beneficiaries) indicated that they do not get any form of monitoring at the farms, while $25.3 \%$ (73 farm beneficiaries) indicated that they receive it from government officials and $16.6 \%$ (48 farm beneficiaries) received it from other service providers. Finally, fourteen farm beneficiaries $(4.8 \%)$ received monitoring from traditional authority and $2.8 \%$ (8 farm beneficiaries) were monitored by the Municipalities (Figure 2). Nonetheless, it is unfortunate that most of the farms are not monitored since land was given back to the previously disadvantaged people.

Government officials: $25.26 \%$

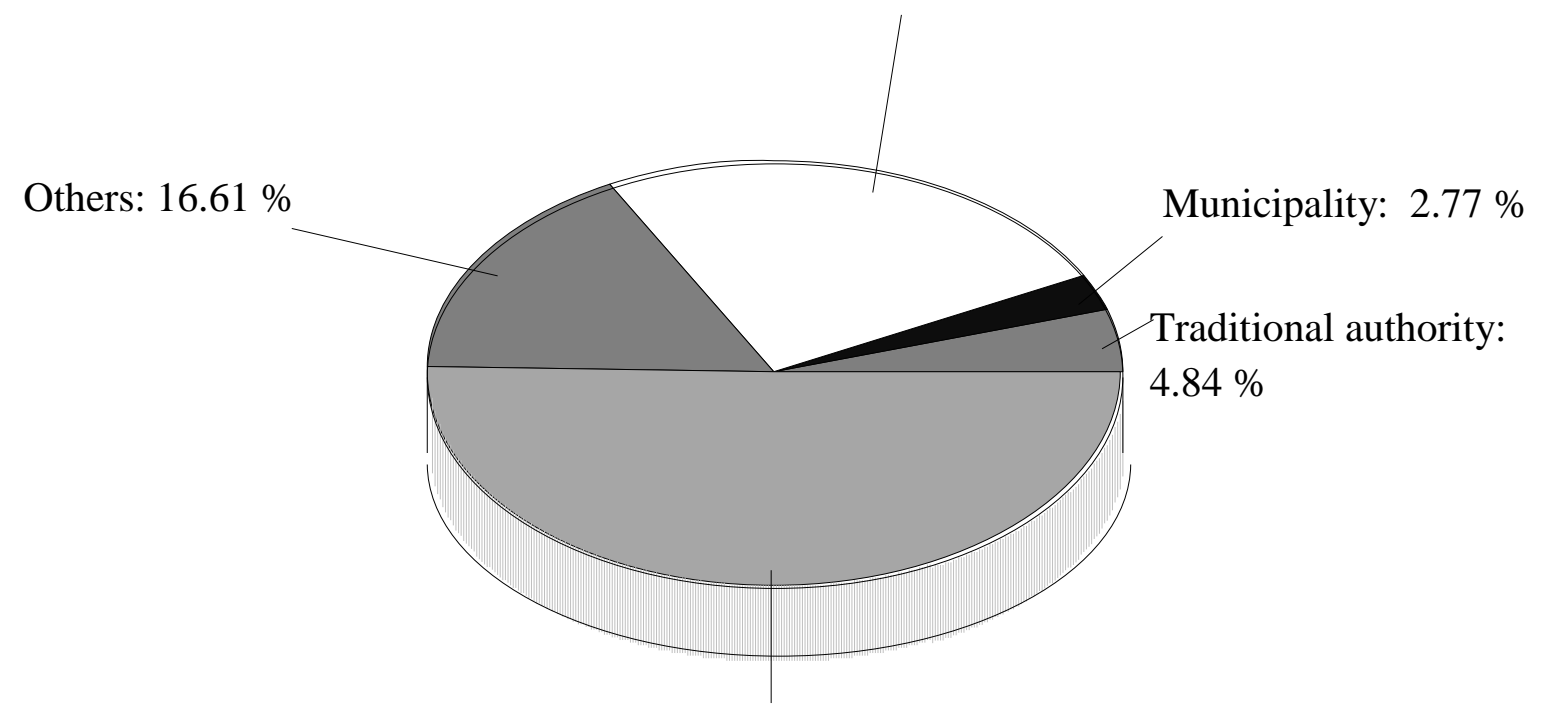

None: $50.52 \%$

\section{FIGURE 2. PIE CHART PRESENTING THE MONITORING OF THE RESTITUTION FARMS BY VARIOUS STAKEHOLDERS}

The study further revealed that the majority of farm beneficiaries did not receive monitoring of their farms while few were monitored. Although some farms were monitored, this was not done properly and intensively because of the infrequency of the visits by the 
government officials who were coming to monitor the farms. The previous study conducted by Anseeuw \& Mathebula (2008) also confirmed lack of monitoring of land reform farms at Molemole Local Municipality in Limpopo Province. The authors revealed that several farm activities were implemented without consultation with the farm beneficiaries due to lack of external monitoring. Adding to this, the current study revealed further that the officials such as Agricultural Extension Advisors (AEA) came occasionally and most of the time, they came when they were called by the farm beneficiaries. However, this type of monitoring was not supposed to be done in that way, instead AEA were supposed to have a schedule that would have guided them about how many times to visit a farm and the main purpose of the visit. Cain (2013) provided a similar scenario of lack of monitoring and support in Angola where farm beneficiaries who owned land in rural areas had many challenges such as lack of support services, in particular from government institutions. This ultimately led to their agricultural infrastructure to collapse. Once the infrastructure collapse, it means that even the farm activities will be compromised.

\section{Frequency of monitoring}

The majority (60.2\%; 174 farm beneficiaries) confirmed that there are no visits by government officials in particular the Department of Agriculture and DRDLR. Most of the beneficiaries think that government officials are reluctant to visit the farms because there is nothing to monitor due to the unproductive land given to the new owners. Close to $15 \%$; 42 farm beneficiaries) indicated that they are monitored on monthly basis. The reason for officials monitoring the farms is because of noticeable production on the farms. About 13.5 \% (39 farm beneficiaries) indicated that they received monitoring once per week, while 11.8 $\%$ (34 farm beneficiaries) were monitored on quarterly basis by all government institutions (Table 1).

TABLE 1. FREQUENCY OF MONITORING OF THE RESTITUTION FARMS

\begin{tabular}{lrr}
\hline Monitoring & Frequency & Proportion (\%) \\
\hline Once per week & 39 & 13.5 \\
Monthly & 42 & 14.5 \\
Quarterly & 34 & 11.8 \\
No monitoring & 174 & 60.2 \\
Total & 289 & 100 \\
\hline
\end{tabular}

Furthermore, the monitoring that was provided to the land reform farms was very poor and it could not help the farm beneficiaries to improve on farm production. During the feedback session most beneficiaries indicated that "we are always on our own at the farms, and when we need assistance either from the government or private sector, nobody is willing to come and help us. If farms are not monitored regularly, we as the farm beneficiaries would start to operate as we wish, and disobey all the plans we would have drafted with Agricultural Extension Advisors and DRDLR officials". It would be a proper if the AEAs and DRDLR can draw schedules either weekly or monthly to visit the farms in order to guide emerging farmers on how to use farms effectively. 
Effectiveness of Land reform programme to improve rural livelihoods

About (48.1\%; 139 farm beneficiaries) indicated that they strongly disagree to the notion that their livelihoods (human, financial, social and physical assets) on the farms has improved since the restoration of the land, $(24.9 \% ; 72)$ disagreed respectively, with $(4.8 \% ; 14)$ respondents undecided (Figure 3). The majority who said land reform farms were not effective since its introduction in rural areas cited reasons like lack of human capital development when beneficiaries were introduced into the programme, and lack of financial capital to kick-start the production process. On many farms, income and job creation were not realised and during the feedback session, most beneficiaries stated that "we lose hope in the land reform farms since we are unable to put bread on our tables at the end of the month". Others are no longer committed to work at the farms, and most of the time they come to the farms after a long time. While $(18.7 \% ; 54)$ of the respondents indicated that they agree and $(3.5 \% ; 10)$ strongly agree respectively that the programme brought some positive changes in their lives because they are able to earn income to use for their basic requirements. They further maintained that more jobs were created for both youth and women, income was generated within the farms, poverty was reduced and food security was achieved among the farm beneficiaries (Figure 3).

\section{Effectiveness of land reform programme to improve rural} livelihoods

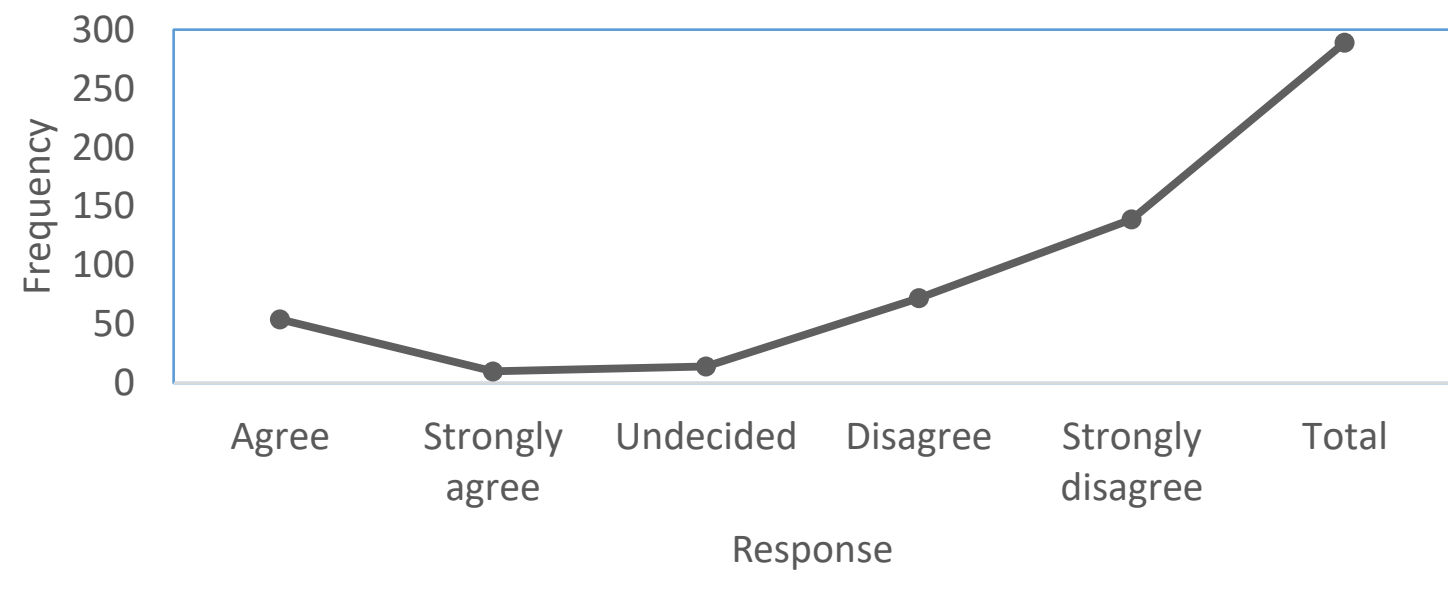

FIGURE 3. EFFECTIVENESS OF LAND REFORM PROGRAMME TO IMPROVE RURAL LIVELLHOODS

Responding to the effectiveness of land reform programme, the majority of farm beneficiaries strongly agreed that the land reform was not effective in enhancing the livelihoods of beneficiaries, because some jobs that were supposed to be created were not realised, farms did not generate income to deal with challenges of poverty, food insecurity and other socio-economic issues among the farm beneficiaries. Reduced farm productivity has ultimately affected food security and livelihoods of farm beneficiaries in the country, rather, agricultural growth should encourage farmers to produce more products in the farms. The same scenario of land reform farms not being effective to improve livelihoods of the beneficiaries was observed in a study on the performance of land reform farms in North West Province conducted by Lubambo (2011). The author discovered that land reform farms failed 
to meet the objectives of the land reform programme. One of the reasons for the failure was based on people who tend to form large groups to access funds to purchase the farm, but in the process bring people who have no farming ambitions. Only few beneficiaries have a passion for farming, while the rest just wait for the benefits (Kirsten et al., 2016). Hence, livelihoods of the farm beneficiaries were not improved. Above all, if production can be maximized using hydroponics and value adding of the products within the farms, more jobs may be increased within the land reform farming sector, that will ultimately help farm beneficiaries to receive financial benefits to improve the livelihoods.

During the feedback session, beneficiaries suggested that every farm or Community Property Association (CPA) should have advisors who would assist beneficiaries in farm development; those advisors should be accessible to the farm beneficiaries through establishing DRDLR site offices in the District and local Municipalities to avoid beneficiaries travelling long distance to get assistance. Furthermore, if the government opt to appoint mentors or strategic partners as advisors who have more skills or farming experience to guide and coach the emerging farmers with less experience on how to use their farms effectively (Mabuza, 2016), the process of appointment from the beginning should involve farm beneficiaries. This means that the community or farm beneficiaries should recommend appointments, then the DRDLR can finalise the appointment.

Determinants and ranking of factors that contributed to non-improvement of livelihoods of farm beneficiaries

The study revealed several factors that determined non-improvement of the livelihoods of the farm beneficiaries. The factors were ranked in terms of their prevalence when interviews were conducted. These factors should be taken into consideration when interventions on farm activities are implemented to enable farmers to address all of these factors, and failure to consider this factors will create unnecessary hindrances towards farm development. These factors are presented in Table 2.

TABLE 2. RANKING OF THE DETERMINANTS THAT CONTRIBUTED TO NON-IMPROVEMENT OF LIVELIHOODS OF THE LAND REFORM FARM BENEFICIARIES

\begin{tabular}{clr}
\hline No & Determinant Factors for Non- improvement of livelihoods & Frequency \\
\hline 1 & Under-utilization of the land reform farms & 291 \\
2 & Lack of farm support from government & 283 \\
3 & lack of mentoring to transfer farming skills to the farm beneficiaries & 204 \\
4 & Declined production of land reform farms & 194 \\
\hline
\end{tabular}

Main drivers of poor performance of the land reform farms

The following aspects in Figure 3 were identified during the study as the main contributors of poor performance of the land reform farms. These poor performance was because of the declining production of the land reform farms: non-utilisation of the farms and insufficient farming skills of the farm beneficiaries who are given land back through the land reform programme. Lack of farming skills subsequently caused beneficiaries not to be commitment because farmers were not clear on what to do with the farms, and where there was production in some other farms, the production was of a poor quality that could not 
match the standard of market demand. Hence most of the farms were abundant by the beneficiaries leading to idle farms. Furthermore, there was no clear strategy with proper guidelines on how farm beneficiaries can use the land effectively to improve their livelihoods. All the aspects that are the main drivers of poor performance of the farms are mentioned at Figure 4.

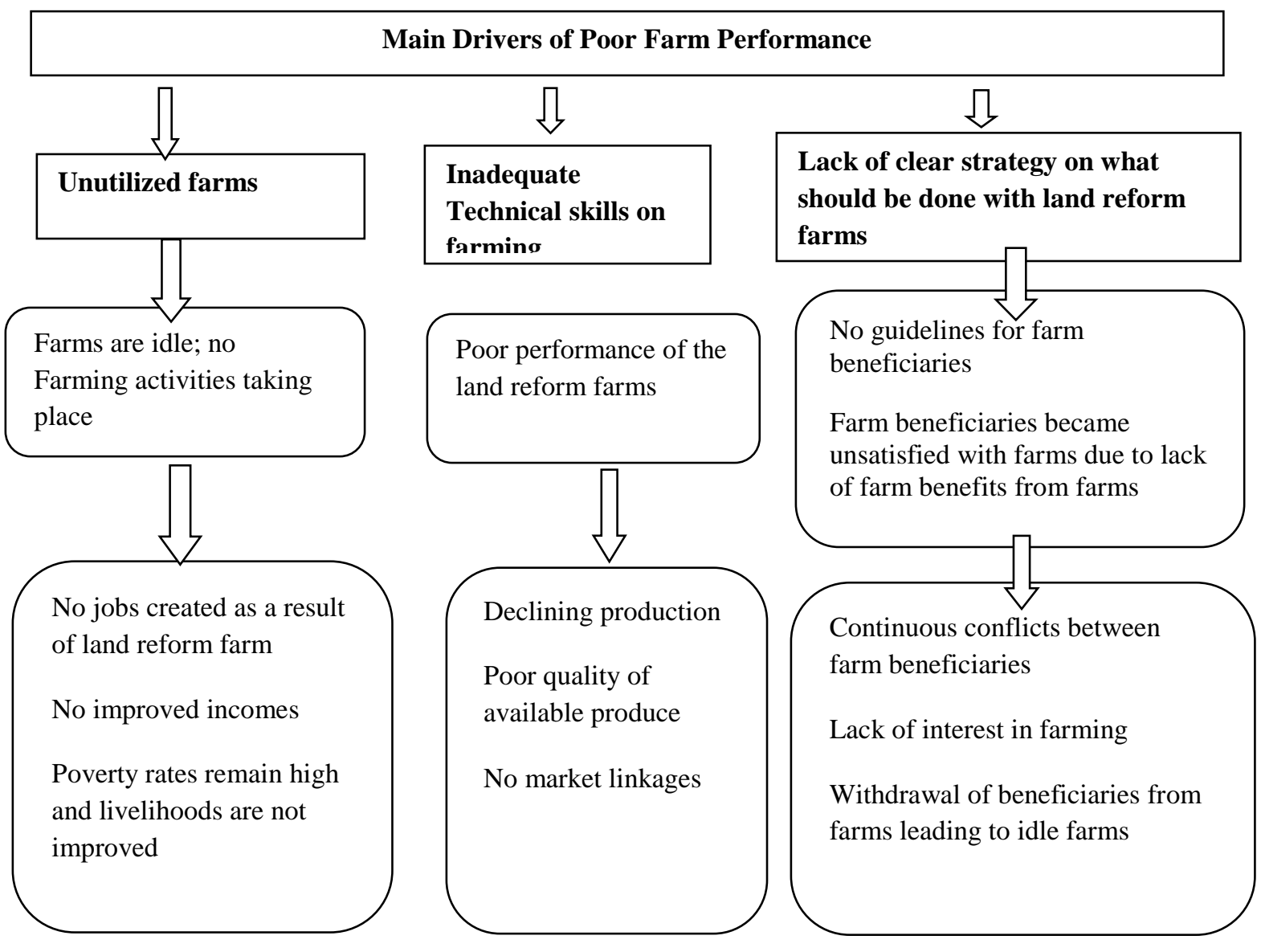

FIGURE 4. MAIN DRIVERS OF POOR FARM PERFORMANCE

The above factors identified that contributed to poor performance of the farms, were used to guide farm beneficiaries on how to improve farm performance by mitigating the abovementioned factors that negatively affected their livelihoods since farm restoration in South Africa. Hence, the study confirmed that livelihoods of the farm beneficiaries have remained the same from the restoration of land until 2015. The farm beneficiaries agreed that land reform is a very good programme if it is implemented correctly. The reasons that were advanced by the farm beneficiaries about ineffectiveness of the land reform programme were that their livelihoods are still the same because of poor production of the farms. Another reason mentioned by the beneficiaries was lack of advisors such as agro-economists, who could advise the farms beneficiaries on how to utilise the farm funds and to invest for the farm. Added to this, the agro-economists should provide agricultural advisory services from the beginning until the farm is sustainable. The farm beneficiaries further mentioned that their livelihoods such as human, financial, social and physical capitals have not improved. 
Human capital that concentrated more on capacity building of the farm beneficiaries, in particular farm production was also not realized. Failure to have adequate farm production would mean that there would not be income that could improve the socio-economic status of the farm beneficiaries. The financial capital from the land reform farms was negatively affected because of farms that were not generating income. Thus, beneficiaries were not able to get salaries or wages at the end of the month to sustain their households. The beneficiaries also mentioned that they were behind in paying for monthly contributions for burial clubs and school fees for their children. The physical capital that deals more with infrastructure in the households of the farm beneficiaries was not realized. The same scenario was mentioned during the appraisal of land reform projects in Mpumalanga, Free State and North-West Provinces. The land reform farms yielded results that confirmed the low levels of success (DRDLR, 2019). It is for this reason that the farm committees are encouraged to incorporate agricultural economics expert to serve as agricultural financial advisors, and agricultural engineers who would unleash their agricultural skills and potential to operate and repair all machines and infrastructure in the farm.

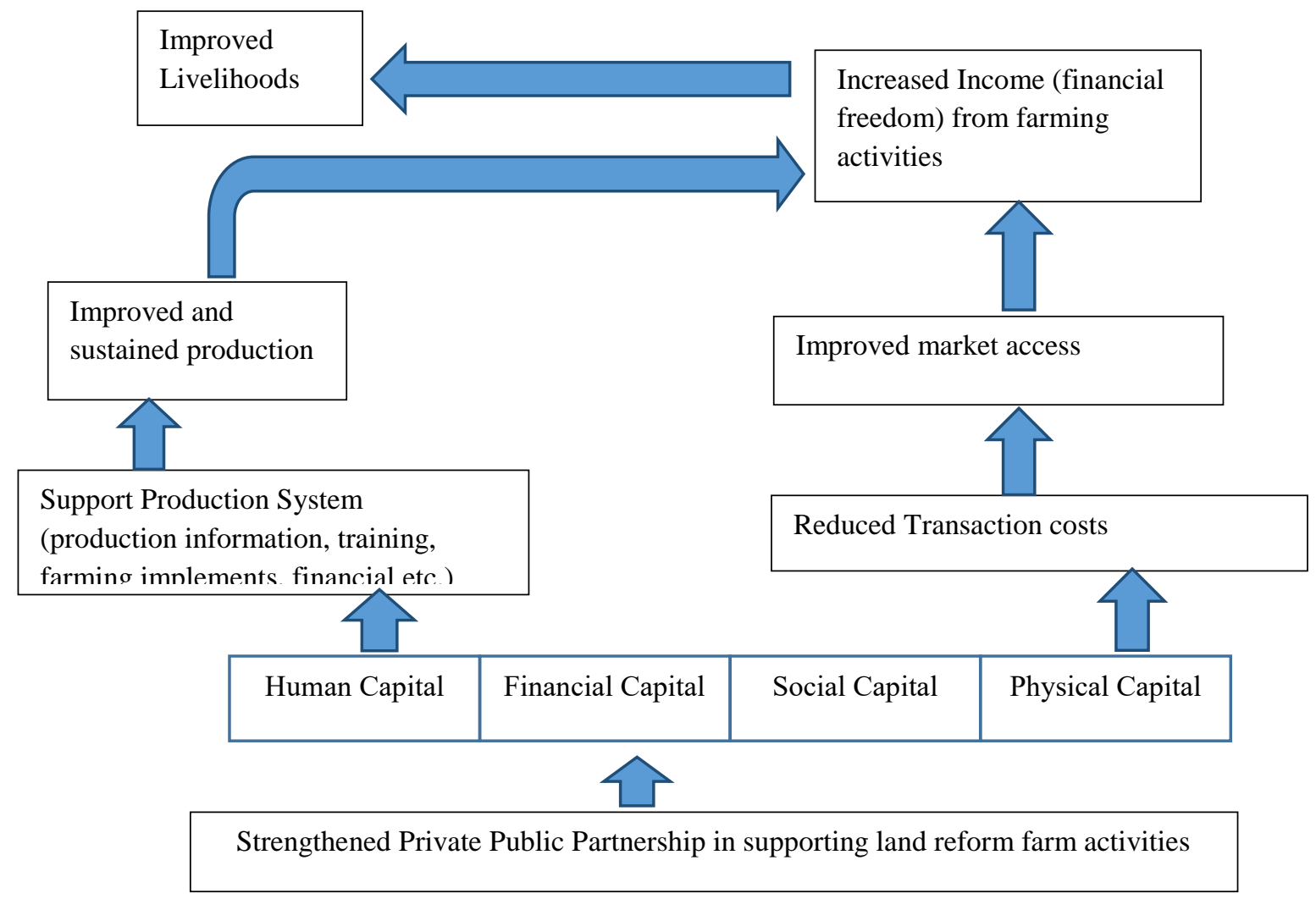

\section{FIGURE 5. INTERVENTION STRATEGY TO IMPROVE LIVELIHOODS OF LAND REFORM FARM BENEFICIARIES}

Above all, failure of the land reform programme to improve the livelihoods of the farm beneficiaries such as human, financial, social and physical capitals due to the challenges experiences by beneficiaries in the farms such as unproductive farms, lack of farm income and salaries of the beneficiaries, the study recommended aspects that are important to develop the intervention strategy in order to assist farmers to use their allocated farms effectively to 
improve livelihoods of the farm beneficiaries. The same aspects that informed the intervention strategy are clearly shown at Figure 5.

\section{CONCLUSIONS}

The study revealed poor performance of the land reform farms due to unavailability of intervention strategy in South Africa, and this contributed negatively towards the improvement of the farm beneficiaries` livelihoods. Most of the land reform farms in South Africa in particular Waterberg District were not utilized, while poor commitment, lack of financial support, lack of resources, continuous conflicts, poor infrastructure, and theft of electric cables and transformers were discovered as the main challenges in the farms. Added to this, majority of farm beneficiaries have not benefited from the land reform farms, and their livelihoods have still not improved. Therefore, the study developed a three-pronged intervention strategy in figure 4 above that serve as the main product emanated from the study to mitigate poor performance of the farms and improve livelihoods of farm beneficiaries, by strengthening Private Public Partnership (PPP) in supporting farm activities in South Africa. The developed strategy is anchored on three key factors: the need for thorough assessment by the government on the farm beneficiary's level of commitment to the farm prior to farm allocation and funding, need to incorporate new experts in agricultural economics and agricultural engineers into the land reform farms personnel to unleash their agricultural expertise. These Agricultural experts should be in the farms to advise farmers on farm management such as financial matters, improved market access, and how to support farm production system that would subsequently improve the livelihoods of the farm beneficiaries in Waterberg District of South Africa and beyond.

\section{ACKNOWLEDGEMENTS}

The researcher acknowledges the research unit of the University of Venda that provided financial support to undertake the study (project no: SARDF/16/IRD/07/2904).

\section{REFERENCES}

Aliber, M \& Cousins, B. (2013). Livelihoods after Land Reform in South Africa. JAC: Journal of Agrarian Change, 13(1): 140-165. Retrieved from https://onlinelibrary.wiley.com/doi/abs/10.1111/joac. 12012

Erlank, W. (2014). Green paper on land reform: Overview and challenges. ELJ: Electronic Law Journal, 17(2):614-639. Retrieved from http://www.saflii.mobi/za/journals/PER/2014/18.html

Hall, R, Wisborg, P, Shirinda, S \& Zamchiya, P. (2013). Farm Workers and Farm Dwellers in Limpopo Province, South Africa. JAC: Journal of Agrarian Change, 13(1): 47-70. Retrieved from https://www.researchgate.net/publication/257358512_Farm_workers_and_fa...

Jiming, C. (2013). On China's Land System Reform. JMCS: Journal of the Modern China Studies, 20(2), 57-73. Retrieved from 
https://www.researchgate.net/publication/309760690_China`s_new_rural_land_re form...

Kirsten, J, Machethe, C, Ndlovu, T \& Lubambo, P. (2016). Performance of Land Reform projects in the North West Province of South Africa: Changes over time and possible causes. JDSA: Journal of Development Southern Africa, 33(4): 442-458. Retrieved from https://repository.up.ac.za/handle/2263/56291

Kloppers, H. J. (2014). Introducing CSR-The Missing Ingredient in the Land Reform Recipe? JPEL: Journal of Potchefstroom Electronic Law, 17(2): 708-758. Retrieved from http://scholar.google.co.za/citations?user=MgEnCAUAAAJ\&hl=en

Lipton, M. (2012). Land reform in developing countries: Property rights and property wrongs. JAE: Journal of Agricultural Economics, 10: 1477-95. Retrieved from https://www.researchgate.net/publication/259760073_Land_Reform_in_Deve...

Nyawo, V. Z. (2014). Zimbabwe Post-Fast Track Land Reform Programme: The different experiences coming through. IJARS: International Journal of African Renaissance Studies, $9(1), \quad 36-49$. $\quad$ Retrieved from https://www.tandfonline.com/doi/abs/10.1080/18186874.2014.916858

Pilossof, R. (2016). Possibilities and Constraints of Market-Led Land Reform in Southern Africa: An analysis of transfers of commercial farmland in postcolonial Zimbabwe, 1980-2000. JAGRAC: Journal of Agrarian Change, 16(1), 32-49. Retrieved from https://onlinelibrary.wiley.com/doi/abs/10.1111/joac.12090

Pringle, E. (2013). Land Reform and White Ownership of agricultural Land in South Africa. JHSF: Journal of the Hellen Suzman Foundation, 70, 37- 42. Retrieved from https://hsf.org.za/publications/focus/focus-70-on-focus/focus-70-oct-e-pringle.pdf

Walker, C. (2012). Finite Land: Challenges Institutionalizing Land Restitution in South Africa, 1995-2000. JSAS: Journal of Southern African Studies, 38(4): 809-826. Retrieved from https://www.landonline.com/doi/abs/10.1080/03057070.2012.0750915

Zenker, O. (2014). New Law against an old state: Land Restitution as a Transition to justice in Post- Apartheid South Africa? JDC: Journal of Development and Change, 45(3), 502-523. Retrieved

from https://onlinelibrary.wiley.com/doi/abs/10.1111/dech.12092

Land Reform Policy Discussion Document, (2012). Government of South Africa, Government publishers: Pretoria. Retrieved from http://www.sahistory.org..za/sites/default/files/landpolicyproposals_june2012v_

Department of Performance Monitoring and Evaluation report, (2013). Government of South Africa, Government publishers, Pretoria. Retrieved from https://www.dpme.gov.za/publications/Strategic\%20plan\%20and\%20Annual...

Cousins, B. (2019). Land Reform in South Africa is failing. Can it be saved?-Transformation 92. University of Western Cape, Cape Town. Retrieved from https://www.plaas.org.za/ben-cousins-2017-land-reform-in-south-africa-is-failing-canit... 
Anseeuw, W \& Mathebula, N. (2008). Land Reform and Development: Evaluating South Africa `s Restitution and Redistribution Programmes. University of Pretoria, Pretoria, South Africa. Retrieved from https://www.researchgate.net/publication/254389747_land_Reform_and_De...

Golele, N. S. (2016). Assessment of the effectiveness of the mentorship programme in land reform: A case of Land Restitution in Sekhukhune District, Limpopo Province. University of Limpopo, Polokwane, South Africa. Retrieved from http://ulspace.ul.ac.za/handle/10386/1595

Lubambo, P. T. (2011). "An appraisal of post-transfer production trends of selected land reform projects in the North West Province, South Africa" (Masters Dissertation in Department of Agricultural Economics, Extensions and Rural Development. University of Pretoria, Pretoria, South Africa. Retrieved from https://pdfs.semanticscholar.org/6a64/0984a8e382466c7a3eaf1304d75358...

Maboa. (2014). Socio-economic analysis of land reform projects at Elias Motsoaledi Local Municipality in the Limpopo Province of South Africa: comparing the degree of contribution to food security. University of South Africa, Pretoria, South Africa. Retrieved from http://uir.unisa.ac.za/bitstream/handle/10500/13513/dissertation_mafora_mh.pdf ,sequ...

Mabuza. (2016). Socio-economic impact of land reform projects benefiting from the Recapitalisation and Development Programme in South Africa. University of Pretoria, Pretoria, South Africa. Retrieved from https://www.up.ac.za/food-security-policyinnovation-lab/articles/2732932/preview? mod...

Van Rooyen, J. (2008). Land Reform in South Africa: Effects on Land Prices and Productivity. Rhodes University, Grahamstown. Retrieved from https://www.researchgate.net/publication/316415617_The_Historical_Conte...

Cain, A. (2013). Angola: Land resources and conflict. In land and post-conflict peace-building, ed. J. Unruh and R. C. Williams. London: Earthscan publishers. Retrieved from http://www.academia.edu/33508396/Angola_Land_Resources_and_Conflict

Hendricks, F. Ntsebeza, L. \& Helliker, K. (2013). The promise of land: Undoing a century of dispossession in South Africa. Jacana Media, Auckland Park. Retrieved from http://Kriegerz.jhu/arrighi/Ntsebeza-The-promise-of-land_chap-1_3_6_1....

Mutanga, S.S. (2011). An Assessment of Livelihood Realities in the Lowveld of Zimbabwe and

Natives Land Act of 1913. Pretoria: Government publishers, Pretoria. Retrieved from http://www.semanticscholar.org/paper/Access-to-land-and-land-ownership-forresde...

DRDLR. (2019). Department of Rural Development and Land Reform report 2019. Pretoria. Retrieved from https://www.gov.za/documents/department-rural-development-andland-reform-annual...

STATSSA. (2011). Statistics South Africa. 2011. Government of South Africa, Government Printers, Pretoria. Retrieved from http://www.statssa.gov.za/?page_id-3839 
STATSSA. (2019). Statistics South Africa. 2019. Government of South Africa, Government Printers, Pretoria. Retrieved from http://www.statssa.gov.za/?m=2019

WDMIDP. (2013). Waterberg District Municipality IDP 2013. Modimolle. Retrieved from http://www.waterberg.gov.za/docs/plans/FINAL\%20IDP\%20201314.pdf

WDMIDP. (2018). Waterberg District Municipality IDP 2018. Modimolle. Retrieved from http://www.waterberg.gov.za/docs/plans/Draft\%202017-18\%201DPpdf

WDMLED. (2014). Waterberg District Municipality Local Economic Development 2014. Waterberg District Municipality, Modimolle. Retrieved from http://www.waterberg.gov.za/docs/sdbip/waterberg\%20LED\%20Strategy\%20... 